Article

\title{
Antibacterial and Biofilm Inhibitory Activity of Medicinal Plant Essential Oils Against Escherichia coli Isolated from UTI Patients
}

\author{
Rihab Lagha ${ }^{1,2}$, Fethi Ben Abdallah ${ }^{1,2, *}$, Badriah Osama AL-Sarhan ${ }^{1}$ and Yassin Al-Sodany ${ }^{1,3}$ \\ 1 Department of Biology, Faculty of Science, Taif University, Taif 11099, Saudi Arabia; \\ rihablagha@yahoo.fr (R.L.); Ruby244@hotmail.com (B.O.A.-S.); yalsodany@yahoo.com (Y.A.-S.) \\ 2 Unité de Recherche: Virologie \& stratégies antivirales, Institut Supérieur de Biotechnologie, Monastir \\ University, Monastir 5000, Tunisia \\ 3 Botany Department, Faculty of Science, Kafr El-Sheikh University, Kafr El-Sheikh 33516, Egypt \\ * Correspondence: fetyben@yahoo.fr; Tel.: +966-502204814
}

Academic Editor: Raphael E. Duval

Received: 28 January 2019; Accepted: 18 March 2019; Published: 23 March 2019

check for updates

\begin{abstract}
Urinary tract infections (UTIs), caused by Escherichia coli $80 \%$ to $85 \%$ of the time, are one of the most important causes of morbidity and health care spending affecting persons of all ages. These infections lead to many difficult problems, especially increasing resistance to antibiotic drugs. Bacterial biofilms play an important role in UTIs, responsible for persistent infections leading to recurrences and relapses. In this study, we have investigated the antibacterial activity of five medicinal plant essential oils against UTIs caused by E. coli using disc diffusion and minimal inhibition concentration (MIC) methods. In addition, biofilm inhibitory action of oils was realized by crystal violet. Gas chromatography-mass spectrometry (GC-MS) analysis showed a variability between oils in terms of compound numbers as well as their percentages. Antibacterial activity was observed only in cases of Origanum majorana, Thymus zygis and Rosmarinus officinalis, while Juniperus communis and Zingiber officinale did not showed any effect towards E. coli isolates. T. zygis essential oil demonstrated the highest antibacterial activity against $E$. coli isolates, followed by O. majorana and R. officinalis. Further, oils showed high biofilm inhibitory action with a percentage of inhibition that ranged from $14.94 \%$ to $94.75 \%$. R. officinalis oil had the highest antibiofilm activity followed by T. zygis and O. majorana. Accordingly, tested oils showed very effective antibacterial and antibiofilm activities against $E$. coli UTIs and can be considered as good alternative for antibiotics substitution.
\end{abstract}

Keywords: Escherichia coli; UTI; essential oils; Origanum majorana; Thymus zygis; Rosmarinus officinalis; Juniperus communis; Zengiber officinale; antibacterial; antibiofilm

\section{Introduction}

Urinary tract infections (UTIs) are a significant cause of morbidity that affects persons of all ages. Approximately $40 \%$ of women have had a UTI at some time in their lives [1]. Escherichia coli (E. coli) is the most frequent agent (about $80 \%$ ) of UTIs in humans and one of the most common causes of Gram-negative nosocomial infections [2]. Further, other bacteria such as Proteus mirabilis, Klebsiella pneumoniae, Pseudomonas aeruginosa, Enterococcus spp., Enterobacter spp., group B Streptococcus, and Staphylococcus saprophyticus are also involved [3]. Recently, UTIs have increased in Saudi Arabia, and the predominant organisms associated with UTI are E. coli and K. pneumoniae, which are highly resistant to commonly used oral agents [4].

Uropathogenic E. coli contains many virulence factors that allow bacteria a resistance to various host defense mechanisms. Among them, type 1 fimbriae and pili are involved in adherence to host 
cells and invasion [5], while toxins and flagella play an important role in pathogen dissemination. Biofilm formation can be considered as the urovirulence determinant responsible for the long-lasting persistence of bacteria in the genitourinary tract [6]. Urinary catheters destroy natural barriers and provide a nidus for infection by serving as a substrate for biofilm formation. Several studies have demonstrated that biofilm cells are more resistant to antimicrobial agents than planktonic bacterial cells [7]. The resistance of biofilms to antibiotics contributes to the persistence of infections, such as those associated with implanted devices [8].

Antimicrobial agents are not effective against biofilms, and there are few novel compounds under development. Increased knowledge regarding biofilm formation has been conducted to recognize several possible points for targeted antibiofilm approaches $[9,10]$

Essential oils (EOs) have been used for hundreds of years as a natural medicine to combat a variety of infections. EOs such as Origanum majorana, Thymus zygis, Rosmarinus officinalis, Juniperus communis and Zengiber officinale have been recorded for their antibacterial, and/or antibiofilm activities [11-15]. Several reports have demonstrated that oregano, thyme and cinnamon EOs have antioxidant properties related with phenolic compounds such as carvacrol and thymol, and these can be used under certain conditions as fungicides and bactericides [16-19]. Prabuseenivasan et al. [20] reported that 19 EOs showed antibacterial activity and demonstrated a significant inhibitory effect by cinnamon, clove, geranium, lemon, lime, orange and rosemary oils against Gram-positive and Gram-negative bacteria. Furthermore, Wojnicz et al. [21] showed that Betula pendula affected the biofilm formation by uropathogenic E. coli, inhibiting between 43-80\% of biofilm formation by E. coli. Kim and Park [22] showed that toluene extract from Z. officinalis inhibited between $39-56 \%$ of biofilm formation by P. aeruginosa (PA14).

Antimicrobial action of EOs has attributed due to the damage of cell wall and cell membrane. Many EOs have relatively low mammalian toxicity and degrade quickly, making them safe [23]. Generally, Gram-negative bacteria are more resistant to EOs than Gram-positive bacteria [24]. As such, the structure of the Gram-positive bacteria cell wall allows hydrophobic molecules to easily penetrate the cells and act on both the cell wall and within the cytoplasm [25].

The aim of this study was to investigate the potential antibacterial and antibiofilm activities of Z. officinale, O. majorana, R. officinalis, J. communis and T. zygis medicinal plants EOs against E. coli associated with urinary tract infection.

\section{Results}

\subsection{Population of the Study}

Out of the 50 patients investigated in this work, we had 35 females (0.7) and 15 males (0.3) with ages ranging from two months to 90 years. The distribution of infected patients based on gender and age is presented in Figure 1.
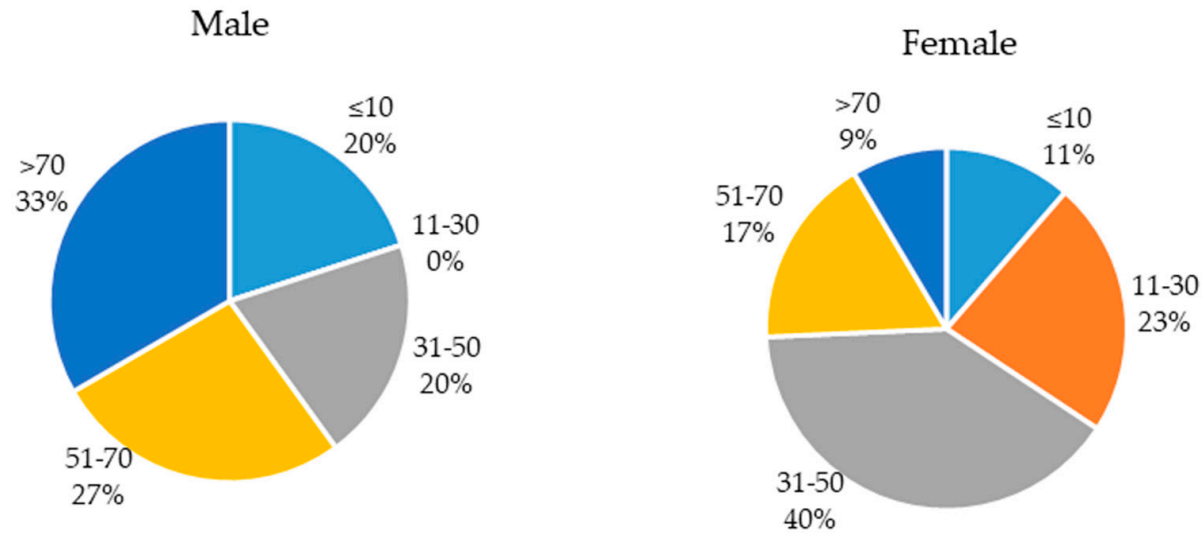

Figure 1. Age distribution of patients in relation to gender. 


\subsection{Chemical Composition of the Essential Oils}

The chemical compositions of J. communis, Z. officinale, O. majorana, T. zygis and R. officinalis EOs are presented in Table 1. GC-MS analysis showed a variability between oils in term of compounds number as well as their percentages. A total of 58 constituents were identified in tested oils and were distributed as follow: 35, 9, 31, 30 and 13 compounds in J. communis, Z. officinale O. majorana, T. zygis and R. officinalis respectively.

Table 1. Chemical composition of the essential oils.

\begin{tabular}{|c|c|c|c|c|c|}
\hline Components & J.communis $\%$ & Z. officinale \% & O. majorana \% & T. zygis \% & R. officinalis \% \\
\hline$\alpha$-Pinene & 47.1 & 2.6 & 0.46 & 3.6 & 11.7 \\
\hline Sabinene & 3.6 & - & 8 & 0.84 & - \\
\hline$\beta$-Pinene & 2.5 & - & 1.4 & 0.33 & 6.3 \\
\hline$\beta$-Myrcene & 11.7 & - & 1.1 & 8.6 & 1.5 \\
\hline$\alpha$-phellandrene & 0.43 & - & 0.30 & 0.48 & - \\
\hline Limonene & 6.2 & 5.7 & 3.5 & 2.6 & 2.2 \\
\hline Terpinen-4-ol & 2.3 & - & 25.9 & 11.7 & - \\
\hline Bornyl acetate & 0.22 & - & - & 0.07 & 0.4 \\
\hline$\beta$-Caryophyllene & 2.8 & - & 2.3 & 1.6 & - \\
\hline$\alpha$-Thujene & 1.1 & - & 0.33 & 0.21 & - \\
\hline Camphene & 0.43 & 7.4 & 0.03 & 0.74 & 3.2 \\
\hline$\Delta 3$-Carene & 0.12 & - & - & - & - \\
\hline$\alpha$-Terpinene & 1.6 & - & 7.7 & 4.2 & - \\
\hline$p$-Cymene & 0.63 & - & 3.4 & 2.2 & 1 \\
\hline 1,8-Cineole & - & 2.6 & 0.15 & - & 47.7 \\
\hline$\gamma$-Terpinene & 2.6 & - & 16.9 & 7.6 & - \\
\hline Terpinolene & 1.6 & - & 1.7 & 2 & - \\
\hline Linalool & 0.07 & - & 10.9 & 39.7 & 0.859 \\
\hline Borneol & 0.1 & - & - & 1.9 & 2 \\
\hline$\alpha$-Terpineol & 0.47 & - & 2.5 & 1.7 & 2.5 \\
\hline$\alpha$-cubebene & - & - & - & - & - \\
\hline$\alpha$-Copaene & 0.48 & - & - & - & - \\
\hline Camphor & - & - & - & 0.22 & 9.6 \\
\hline$\beta$-Elemene & 0.84 & - & - & - & - \\
\hline$\gamma$-Elemene & 0.67 & - & - & - & - \\
\hline trans- $\beta$-pharnesene & 0.49 & - & - & - & - \\
\hline$\alpha$-Humulene & 2 & - & 0.05 & - & - \\
\hline$\gamma$-Muurolene & 0.7 & - & - & - & - \\
\hline Germacrene D & 1.2 & - & - & - & - \\
\hline cis and trans-thujan-4-ol & - & - & $2.2-2.3$ & $0.88-2.2$ & - \\
\hline cis and trans piperitol & - & - & $0.13-0.18$ & $0.13-0.08$ & - \\
\hline Linalyl acetate & - & - & 7 & 0.5 & - \\
\hline Carvacrol & - & - & 0.03 & 0.08 & - \\
\hline Thymol & - & - & 0.05 & 0.52 & - \\
\hline Bicyclogermacrene & - & - & 0.41 & 0.16 & - \\
\hline $\begin{array}{l}\text { Cis and } \\
\text { trans-p-menth-2-en-1-ol }\end{array}$ & - & - & $0.59-0.32$ & $0.37-0.25$ & - \\
\hline$\alpha$-Selinene & Trace & - & - & - & - \\
\hline$\beta$-Selinene & 0.27 & - & - & - & - \\
\hline$\alpha$-Muurolene & 1.1 & - & - & - & - \\
\hline$\gamma$-Cadinene & 0.52 & - & - & - & - \\
\hline$\delta$-Cadinene & 2 & - & - & - & - \\
\hline Germacrene B & 0.14 & - & - & - & - \\
\hline T-Cadinol & 0.06 & - & - & - & - \\
\hline$\alpha$-Cadinol & 0.1 & - & - & - & - \\
\hline T-Muurolol & 0.13 & - & - & - & - \\
\hline Caryophyllene oxide & - & - & 0.04 & - & - \\
\hline Ocimene & - & - & 0.07 & - & - \\
\hline Spathulenol & - & - & 0.01 & - & - \\
\hline cis-Dihydrocarvone & - & - & - & 0.17 & - \\
\hline trans-Dihydrocarvone & - & - & - & 0.2 & - \\
\hline Verbenone & - & - & - & - & 0.2 \\
\hline ar-curcumene & - & 8 & - & - & - \\
\hline$\alpha$-Zingiberene & - & 33.1 & - & - & - \\
\hline$\alpha$-Farnesene & - & 3.4 & - & - & - \\
\hline$\beta$-Bisabolene & - & 6.4 & - & - & - \\
\hline$\beta$-Sesquiphellandrene & - & 13.5 & - & - & - \\
\hline
\end{tabular}


The major components of $J$. communis EO were $\alpha$-Pinene (47.1\%), $\beta$-Myrcene $(11.7 \%)$ and Limonene (6.2\%); those of Z. officinale were $\alpha$-Zingiberene (33.1\%), $\beta$-Sesquiphellandrene (13.5\%), ar-curcumene $(8 \%), \beta$-Bisabolene $(6.4 \%)$, Camphene (7.4\%) and Limonene (5.7\%). Furthermore, the main components of $O$. majorana EO were Terpinen-4-ol (25.9\%), $\gamma$-Terpinene (16.9\%), Linalool $(10.9 \%)$, Sabinene $(8 \%)$ and $\alpha$-Terpinene $(7.7 \%)$. In addition, the major constituents of $T$. zygis were Linalool (39.7\%), Terpinen-4-ol (11.7\%), $\beta$-Myrcene $(8.6 \%)$ and $\gamma$-Terpinene $(7.6 \%)$. Finally, the primary components of R. officinalis were 1,8-Cineole (47.7\%), $\alpha$-Pinene $(11.7 \%)$, Camphor $(9.6 \%)$ and $\beta$-Pinene (6.3\%).

\subsection{Antibacterial Activity of Essential Oils Against E. coli}

\subsubsection{Disc Diffusion}

Antibacterial effect of EOs against E. coli studied by the disc diffusion method is shown in Table 2. Antibacterial activity was observed only in cases of O. majorana, T. zygis and R. officinalis, while J. communis and Z. officinale did not show any effect on the E. coli isolates. Of the three oils, T. zygis EO showed strong inhibitory action ( $90 \%$ of the isolates), followed by O. majorana and R. officinalis which have a strong inhibitory action on $26 \%$ and $14 \%$ of the isolates, respectively. Furthermore, based on the high percentage of antibacterial effect, T. zygis EO had a strong inhibitory action on $90 \%$ of the isolates, O. majorana had a complete inhibitory action on $60 \%$ of the isolates and $R$. officinalis had a slight inhibitory action on $42 \%$ of the isolates. Therefore, T. zygis EO appeared as the best antibacterial compound, followed by O. majorana with R. officinalis ranked third. Based on the gender and age of the specimens, globally, we have observed the same results in cases of total isolates. T. zygis was considered as an EO with strong inhibitory action followed by O. majorana and R. officinalis.

Table 2. Antibacterial activity of essential oils against $E$. coli isolates using disc diffusion.

\begin{tabular}{|c|c|c|c|c|c|}
\hline \multirow{3}{*}{ Essential Oils } & \multicolumn{5}{|c|}{ E. coli Isolates } \\
\hline & $(++++)$ & $(+++)$ & $(++)$ & $(+)$ & $(-)$ \\
\hline & $n(\%)$ & $n(\%)$ & $n(\%)$ & $n(\%)$ & $n(\%)$ \\
\hline J. communis & & & & & $50(100 \%)$ \\
\hline Z. officinale & & & & & $50(100 \%)$ \\
\hline O. majorana & $13(26 \%)$ & $30(60 \%)$ & $5(10 \%)$ & $2(4 \%)$ & $0 \%$ \\
\hline T. zygis & $45(90 \%)$ & $2(4 \%)$ & $3(6 \%)$ & & $0 \%$ \\
\hline R. officinalis & $7(14 \%)$ & $12(24 \%)$ & $10(20 \%)$ & $21(42 \%)$ & $0 \%$ \\
\hline
\end{tabular}

Strong inhibitory action $(++++)$, Complete inhibitory action $(+++)$, Partial inhibitory action $(++)$, Slight inhibitory action $(+)$ and no inhibitory action $(-), n$ : number of isolates.

\subsubsection{Antibacterial Activity of MIC and MBC}

Antibacterial activity of EOs was evaluated by determining minimal inhibition concentrations (MICs) and minimal bactericidal concentrations (MBCs) in relation to the $50 \mathrm{E}$. coli isolates and reference strain (Table 3). The MIC values of O. majorana EO ranged from $0.19 \mathrm{mg} / \mathrm{mL}$ to $0.78 \mathrm{mg} / \mathrm{mL}$, while the $\mathrm{MBC}$ values ranged from $1.56 \mathrm{mg} / \mathrm{mL}$ to $12.5 \mathrm{mg} / \mathrm{mL}$. These results indicated that bacteria isolated from female children (MIC from 0.19 to $0.39 \mathrm{mg} / \mathrm{mL}$ and $\mathrm{MBC}$ at $1.56 \mathrm{mg} / \mathrm{mL}$ ) were more sensitive to this oil compared to other isolates. Further, strains isolated from male adults were the most resistant with $\mathrm{MBC}$ values going up $12.5 \mathrm{mg} / \mathrm{mL}$.

The MIC values of T. zygis EO were in the range of $0.19 \mathrm{mg} / \mathrm{mL}$ to $0.78 \mathrm{mg} / \mathrm{mL}$, while the MBC values were in the range of $1.56 \mathrm{mg} / \mathrm{mL}$ to $6.25 \mathrm{mg} / \mathrm{mL}$. The most sensitive bacteria were isolated from male children (MIC at $0.19 \mathrm{mg} / \mathrm{mL}$ and MBC at $1.56 \mathrm{mg} / \mathrm{mL}$ ). However, all the isolates reacted in the same way to R. officinalis (MIC from 1.56 to $3.125 \mathrm{mg} / \mathrm{mL}$ and MBC at $12.5 \mathrm{mg} / \mathrm{mL}$ ). T. zygis EO demonstrated the highest antibacterial activity against E. coli isolates compared to O. majorana and R. officinalis. 
Person correlation ( $\mathrm{r}$ ) indicated that there was a significant positive correlation between age and MIC of T. zygis oil ( $r=0.289, P<0.05)$, a non-significant positive correlation between age and MIC of R. officinalis oil ( $r=0.213, p>0.05)$ and a non-significant negative correlation between age and MIC of O. majorana oil $(r=-0.082, p>0.05)$.

Table 3. The minimal inhibition concentration (MIC) and minimal bactericidal concentration (MBC) values $(\mathrm{mg} / \mathrm{mL}$ ) of essential oils (Eos) against E. coli isolates tested with micro-dilution assay.

\begin{tabular}{llllllc}
\hline \multirow{2}{*}{ Isolates } & \multicolumn{2}{c}{ O. majorana } & \multicolumn{2}{c}{ T. zygis } & \multicolumn{2}{c}{ R. officinalis } \\
\cline { 2 - 7 } & \multicolumn{1}{c}{ MBC } & \multicolumn{1}{c}{ MIC } & MBC & MIC & MBC & MIC \\
\hline All samples & $1.56-12.5$ & $0.19-0.78$ & $1.56-6.25$ & $0.19-0.78$ & 12.5 & $1.56-3.125$ \\
Males & $1.56-12.5$ & $0.19-0.78$ & $1.56-3.125$ & $0.19-0.78$ & 12.5 & $1.56-3.125$ \\
Adult males & $1.56-12.5$ & $0.19-0.78$ & $1.56-3.125$ & $0.19-0.78$ & 12.5 & $1.56-3.125$ \\
Children males & 1.56 & $0.19-0.78$ & 1.56 & 0.19 & 12.5 & $1.56-3.125$ \\
Females & $1.56-3.125$ & $0.19-0.78$ & $1.56-6.25$ & $0.19-0.78$ & 12.5 & $1.56-3.125$ \\
Adult females & $1.56-3.125$ & $0.19-0.78$ & $1.56-6.25$ & $0.19-0.78$ & 12.5 & $1.56-3.125$ \\
Children females & 1.56 & $0.19-0.39$ & $1.56-6.25$ & $0.19-0.39$ & 12.5 & $1.56-3.125$ \\
\hline
\end{tabular}

\subsection{Biofilm Formation}

Fifty E. coli UTI isolates were screened for their abilities to form a biofilm on polystyrene surface (Table 4 ). The results showed that $44 \%$ of the isolates were able to form biofilm with optical density 570 (OD570) values ranging from 0.102 to 0.543 and were considered as low-grade positive, whereas the other strains did not show any biofilm formation. The majority of biofilm-forming bacteria were isolated from adult female samples (17 isolates), while only one strain was isolated from a child. Five strains isolated from males were considered as low-grade positive. Reference E. coli ATCC 25922 appeared as a low-grade positive biofilm. Analysis of variance (ANOVA) indicated that there was a non-significant effect of age $(\mathrm{F}=0.758, p>0.05)$ or gender $(\mathrm{F}=0.489, p>0.05)$ of the specimen on biofilm formation.

Table 4. Biofilm formation on polystyrene surface of $E$. coli isolates.

\begin{tabular}{cccccc}
\hline Isolates & OD570 \pm SD & Biofilm Formation & Isolates & OD570 \pm SD & Biofilm Formation \\
\hline 1 & $0.025 \pm 0.012$ & Negative & 26 & $0.166 \pm 0.038$ & low-grade positive \\
2 & $0.025 \pm 0.008$ & Negative & 27 & $0.139 \pm 0.025$ & low-grade positive \\
3 & $0.041 \pm 0.006$ & Negative & 28 & $0.175 \pm 0.013$ & low-grade positive \\
4 & $0.104 \pm 0.039$ & low-grade positive & 29 & $0.543 \pm 0.02$ & low-grade positive \\
5 & $0.286 \pm 0.019$ & low-grade positive & 30 & $0.279 \pm 0.041$ & low-grade positive \\
6 & $0.174 \pm 0.058$ & low-grade positive & 31 & $0.292 \pm 0.03$ & low-grade positive \\
7 & $0.160 \pm 0.045$ & low-grade positive & 32 & $0.142 \pm 0.018$ & low-grade positive \\
8 & $0.183 \pm 0.078$ & low-grade positive & 33 & $0.019 \pm 0.008$ & Negative \\
9 & $0.015 \pm 0.003$ & Negative & 34 & $0.021 \pm 0.015$ & Negative \\
10 & $0.030 \pm 0.005$ & Negative & 35 & $0.011 \pm 0.022$ & Negative \\
11 & $0.093 \pm 0.016$ & Negative & 36 & $0.068 \pm 0.038$ & Negative \\
12 & $0.046 \pm 0.009$ & Negative & 37 & $0.058 \pm 0.049$ & Negative \\
13 & $0.145 \pm 0.011$ & low-grade positive & 38 & $0.063 \pm 0.032$ & Negative \\
14 & $0.059 \pm 0.018$ & Negative & 39 & $0.031 \pm 0.006$ & Negative \\
15 & $0.171 \pm 0.087$ & low-grade positive & 40 & $0.026 \pm 0.008$ & Negative \\
16 & $0.355 \pm 0.076$ & low-grade positive & 41 & $0.042 \pm 0.058$ & Negative \\
17 & $0.102 \pm 0.036$ & low-grade positive & 42 & $0.093 \pm 0.035$ & Negative \\
18 & $0.426 \pm 0.068$ & low-grade positive & 43 & $0.104 \pm 0.011$ & low-grade positive \\
19 & $0.110 \pm 0.022$ & low-grade positive & 44 & $0.096 \pm 0.053$ & Negative \\
20 & $0.025 \pm 0.006$ & Negative & 45 & $0.02 \pm 0.019$ & Negative \\
21 & $0.018 \pm 0.016$ & Negative & 46 & $0.021 \pm 0.008$ & Negative \\
22 & $0.030 \pm 0.013$ & Negative & 47 & $0.166 \pm 0.027$ & low-grade positive \\
23 & $0.018 \pm 0.008$ & Negative & 48 & $0.104 \pm 0.041$ & low-grade positive \\
24 & $0.030 \pm 0.004$ & Negative & 49 & $0.024 \pm 0.05$ & Negative \\
25 & $0.347 \pm 0.012$ & low-grade positive & 50 & $0.037 \pm 0.009$ & Negative \\
ATCC 25922 & $0.115 \pm 0.028$ & low-grade positive & & & \\
\hline
\end{tabular}




\subsection{Biofilm Inhibitory Activity of Essentials Oils}

Antibiofilm activities of T. zygis, O. majorana and R. officinalis EOs are presented in Table 5. The strains used in this part of investigation were selected from the isolates used for biofilm formation potential. In total, 22 isolates considered as low-grade positive biofilm and the reference strain were used.

Firstly, O. majorana EO showed an antibiofilm effect on $50 \%$ of the isolates (11 strains). Among them, 8 isolates (36.36\%) became biofilm negative but no effect was reported on the reference strain with percentage of inhibition ranging from $14.94 \%$ to $88.21 \%$. For T. zygis, we observed antibiofilm activity on $63.63 \%$ of the isolates (14 strains) with a percentage of inhibition varying from $17.81 \%$ to $85.81 \%$. Further, 9 isolates (40.9\%) changed from low-grade positive to biofilm negative in addition to the reference strain. $R$. officinalis EO demonstrated an antibiofilm effect on $86.36 \%$ of the isolates (19 strains). Among them, 17 isolates (77.27\%) became biofilm negative in addition to the reference strain. The percentage of inhibition ranged from $28.84 \%$ to $94.75 \%$.

The outcomes of the present work showed that, R. officinalis EO had the highest antibiofilm activity against E. coli followed by T. zygis and O. majorana.

Table 5. Biofilm inhibitory activity of essential oils against E. coli.

\begin{tabular}{|c|c|c|c|c|c|c|c|}
\hline Isolates & $\begin{array}{c}\text { Control } \\
\text { OD570 } \pm \text { SD }\end{array}$ & $\begin{array}{l}\text { O. majorana } \\
\text { OD570 } \pm \text { SD }\end{array}$ & $\begin{array}{c}\text { Inhibition } \\
(\%)\end{array}$ & $\begin{array}{c}\text { T. zygis } \\
\text { OD570 } \pm \text { SD }\end{array}$ & Inhibition (\%) & $\begin{array}{l}\text { R. officinalis } \\
\text { OD570 } \pm \text { SD }\end{array}$ & $\begin{array}{c}\text { Inhibition } \\
(\%)\end{array}$ \\
\hline 4 & $0.104 \pm 0.039$ & $0.103 \pm 0.019$ & 0 & $0.103 \pm 0.044$ & 0 & $0.105 \pm 0.044$ & 0 \\
\hline 5 & $0.286 \pm 0.019$ & $0.285 \pm 0.089$ & 0 & $0.183 \pm 0.029$ & 36.01 & $0.015 \pm 0.006$ & 94.75 \\
\hline 6 & $0.174 \pm 0.058$ & $0.148 \pm 0.022$ & 14.94 & $0.143 \pm 0.009$ & 17.81 & $0.110 \pm 0.013$ & 36.78 \\
\hline 7 & $0.160 \pm 0.045$ & $0.164 \pm 0.043$ & 0 & $0.079 \pm 0.003$ & 50.62 & $0.059 \pm 0.004$ & 63.12 \\
\hline 8 & $0.183 \pm 0.078$ & $0.181 \pm 0.037$ & 0 & $0.083 \pm 0.006$ & 54.64 & $0.041 \pm 0.008$ & 77.59 \\
\hline 13 & $0.145 \pm 0.011$ & $0.146 \pm 0.025$ & 0 & $0.144 \pm 0.028$ & 0 & $0.063 \pm 0.006$ & 56.55 \\
\hline 15 & $0.171 \pm 0.087$ & $0.109 \pm 0.014$ & 36.25 & $0.108 \pm 0.019$ & 36.84 & $0.021 \pm 0.004$ & 87.71 \\
\hline $16 *$ & $0.355 \pm 0.076$ & $0.099 \pm 0.008$ & 72.11 & $0.073 \pm 0.004$ & 79.43 & $0.032 \pm 0.008$ & 90.98 \\
\hline $17 *$ & $0.102 \pm 0.036$ & $0.086 \pm 0.003$ & 28.33 & $0.103 \pm 0.013$ & 0 & $0.043 \pm 0.002$ & 64.16 \\
\hline $18 *$ & $0.426 \pm 0.068$ & $0.089 \pm 0.009$ & 79.10 & $0.171 \pm 0.032$ & 59.85 & $0.080 \pm 0.004$ & 81.22 \\
\hline 19 & $0.110 \pm 0.022$ & $0.109 \pm 0.007$ & 0 & $0.118 \pm 0.015$ & 0 & $0.113 \pm 0.011$ & 0 \\
\hline $25 *$ & $0.347 \pm 0.012$ & $0.342 \pm 0.079$ & 0 & $0.084 \pm 0.004$ & 75.79 & $0.057 \pm 0.005$ & 83.57 \\
\hline $26 *$ & $0.166 \pm 0.038$ & $0.041 \pm 0.009$ & 75.30 & $0.097 \pm 0.029$ & 41.56 & $0.021 \pm 0.004$ & 87.34 \\
\hline 27 & $0.139 \pm 0.025$ & $0.137 \pm 0.018$ & 0 & $0.076 \pm 0.017$ & 45.32 & $0.015 \pm 0.003$ & 89.2 \\
\hline 28 & $0.175 \pm 0.013$ & $0.172 \pm 0.021$ & 0 & $0.174 \pm 0.024$ & 0 & $0.176 \pm 0.012$ & 0 \\
\hline $29 *$ & $0.543 \pm 0.02$ & $0.064 \pm 0.005$ & 88.21 & $0.077 \pm 0.009$ & 85.81 & $0.031 \pm 0.007$ & 94.29 \\
\hline $30 *$ & $0.279 \pm 0.041$ & $0.075 \pm 0.008$ & 73.11 & $0.098 \pm 0.006$ & 64.87 & $0.058 \pm 0.003$ & 79.21 \\
\hline 31 & $0.292 \pm 0.03$ & $0.084 \pm 0.004$ & 71.23 & $0.165 \pm 0.004$ & 43.49 & $0.045 \pm 0.008$ & 84.58 \\
\hline $32 *$ & $0.142 \pm 0.018$ & $0.140 \pm 0.029$ & 0 & $0.089 \pm 0.003$ & 36.42 & $0.071 \pm 0.005$ & 49.28 \\
\hline $43 *$ & $0.104 \pm 0.011$ & $0.044 \pm 0.004$ & 57.69 & $0.105 \pm 0.012$ & 0 & $0.074 \pm 0.006$ & 28.84 \\
\hline $47 *$ & $0.166 \pm 0.027$ & $0.102 \pm 0.016$ & 38.55 & $0.162 \pm 0.019$ & 0 & $0.099 \pm 0.004$ & 40.36 \\
\hline $48 *$ & $0.104 \pm 0.041$ & $0.103 \pm 0.023$ & 0 & $0.103 \pm 0.044$ & 0 & $0.044 \pm 0.009$ & 57.69 \\
\hline ATCC 25922 * & $0.115 \pm 0.028$ & $0.114 \pm 0.017$ & 0 & $0.071 \pm 0.006$ & 38.26 & $0.059 \pm 0.006$ & 48.69 \\
\hline
\end{tabular}

*: Isolates became biofilm negative after treatment with EOs.

Person correlation $(r)$ indicated that there was non-significant negative correlation between MIC and antibiofilm of both $R$. officinalis $(r=-0.08, p>0.05)$ and T. zygis $(r=-0.04, p>0.05)$, however, there was a non-significant positive correlation between MIC and biofilm of $O$. majorana $(r=-0.129$, $p>0.05)$.

\section{Discussion}

Urinary tract infections (UTIs) are serious health affecting problems worldwide [26]. E. coli accounts for approximately $85 \%$ of community acquired UTIs and 50\% of hospital acquired UTIs [27]. According to Iqbal et al. [28], factors like age, gender, immuno-suppression and urological instruments may affect the prevalence of UTIs. This study was carried out on 50 E. coli isolates, among them four strains isolated from female children and three strains isolated from male children. Based on gender we noted the predominance of females, and based on age we noted the predominance of adults with UTI. The adult females have the highest prevalence in UTI than males, as well as in case of the child. This is in accordance with results developed by Daoud and Afif in Lebanon [29] and Kumar et al. 
in India [30]. According to these authors, the prevalence of UTIs in females is principally owing to anatomic and physical factors.

EOs have largely been employed for their antibacterial, antifungal and insecticidal activities. At present, approximately $3000 \mathrm{EOs}$ are known, 300 of which are commercially important especially for the pharmaceutical, agronomic, food, sanitary, cosmetic and perfume industries. In our study, five medicinal plant EOs were tested for their antibacterial activities using disc diffusion, MIC and MBC methods. Activity against E. coli isolates was observed only in cases of O. majorana, T. zygis and R. officinalis, while J. communis and Z. officinale did not show any effects. Of the three oils, T. zygis showed the highest antibacterial effect on $E$. coli isolates, followed by $O$. majorana. The lowest antibacterial effect was observed with $R$. officinalis EO. Based on biochemical specificity, the highest antibacterial activity of T. zygis is due to linalool (39.7\%). This alcohol has significant bactericidal and bacteriostatic effects. This finding is in accordance with the report of Pattnaik et al. [31] who demonstrated that linalool has a strong effect against a number of different bacteria and fungi. In addition, other major compounds such as Terpinen-4-ol (11.7\%), $\beta$-Myrcene $(8.6 \%)$ and $\gamma$-Terpinene $(7.6 \%)$ increased the antibacterial activity of T. zygis and may explain the effect of $O$. majorana since these three major compounds exist in both oils. Principally, the antibacterial activity of $O$. majorana could be related to its high content $(25.9 \%)$ of the monoterpene alcohol, terpinene-4-ol [32]. The highest antibacterial effect of T. zygis compared to O. majorana can be explained by the high presence of linalool. Further, the antibacterial property of R. officinalis can be attributed to the presence of 1,8-cineole (47.7\%) and camphor (9.6\%) [33], in addition to $\alpha$-Pinene $(11.7 \%)$ and $\beta$-Pinene $(6.3 \%)$. It has been shown that 1,8 -cineole produce alterations on the structure of E. coli, S. enteritidis and S. aureus [34]. The chemical structure of EOs components affects their precise mode of action and antibacterial activity [35]. According to Faleiro et al. [36] activity of T. zygis and O. majorana is owed to the formation of antibacterial substances from their precursors. The precursors of carvacrol and thymol are p-cymene and $\alpha$-terpinene. Generally, Gram-negative bacteria are known to be less susceptible to EOs due to the presence of lipopolysaccharide in their cell wall [37]. However, in this work, O. majorana, T. zygis and R. officinalis EOs demonstrated a very important antibacterial activity against $E$. coli UTIs. J. communis and Z. officinale did not show any effect against $E$. coli isolates, in accordance with the reports of Sivasothy et al. [11] and Pepeljnjak et al. [12], who demonstrated that $E$. coli is the most resistant strain to J. communis and Z. officinale EOs among many Gram-negative and Gram-positive bacteria.

Results of the biofilm formation on polystyrene showed that $44 \%$ of the isolates (22 isolates) were able to form biofilm with OD570 values ranging from 0.102 to 0.543 and were considered as low-grade positive. Biofilm development is estimated to be responsible for over $65 \%$ of nosocomial infections and $80 \%$ of all microbial infections [10], with urology being one of the main fields in which biofilm can become a serious problem [38]. Biofilms are considered as a virulence factor responsible for the long persistence of bacteria in the genitourinary tract [39]. According to Tabibian et al. [7], and Romling, and Balsalobre [10], biofilm markedly impedes the treatment of UTIs by protecting encased bacteria from both the host immune response and antimicrobial therapy. This can explain the prevalence and the persistence of E. coli UTIs in Saudi hospitals.

Biofilm formation has been associated with medical devices including catheters, ventilators, contact lenses and their treatment becomes increasingly difficult. Thereby, the use of a new natural compound in order to inhibit or eradicate biofilm is of great importance. In this investigation, antibiofilm activity of EOs demonstrated that O. majorana had an effect on $50 \%$ of the isolates with a percentage of inhibition ranging from $14.94 \%$ to $88.21 \%$, T. zygis presented activity on $63.63 \%$ of the isolates with a percentage of inhibition varying from $17.81 \%$ to $85.81 \%$, and $R$. officinalis showed an antibiofilm effect on $86.36 \%$ of the isolates with a percentage of inhibition ranging from $28.84 \%$ to $94.75 \%$. Thereby, R. officinalis EO has the highest biofilm inhibition activity against E. coli followed by T. zygis and O. majorana. Despite the high antibacterial effect observed in the cases of T. zygis, O. majorana and R. officinalis, it appears that the oil with the highest antibiofilm activity has the lowest antibacterial effect and this result has been confirmed by statistical analysis. Indeed, a non-significant 
correlation was found between the MIC of oils and antibiofilm activities. Based on biochemical composition, 1.8-cineole present in R. officinalis does more to inhibit the biofilm formation compared to the linalool and terpinen-4-ol present in T. zygis and O. majorana Eos, which are the compounds with the highest content. The inhibition of $E$. coli biofilm found in this study suggests that the addition of EOs prior to biofilm formation may contribute to eliminate planktonic cells, and additionally convert the abiotic surface to be less susceptible to cell adhesion. Pretreatment of the surface with plant extracts produces an unfavourable film that promotes detachment, thereby reducing the surface adherence [40]. Several report have shown that the biofilm could be removed effectively by EOs such as cinnamon oil [41], eucalyptus [42] and tea tree oil [43]. Moreover, in this study, we found for the first time that R. officinalis, T. zygis and O. majorana EOs play a role in the inhibition of biofilm formed by E. coli UTIs. According to Ceylan et al. [44], the amount of biofilm formed by S. aureus was reduced to $60.76 \%$ after treatment with $R$. officinalis EO. EOs could diffuse through the polysaccharide matrix of the mature biofilm and destabilize it due to strong intrinsic antimicrobial activities [45]. Additionally, the anti-adherent activity is explained by the alteration of bacterial surface proteins due to their interactions with oils. This will inhibit the initial attachment phase to the abiotic surface [45]. These results support the medical application of these oils for the prevention and/or treatment of certain infections and diseases.

\section{Conclusions}

Recently, treatment of E. coli infection has become more difficult. This is due to the emergence of multidrug resistant strains. This finding demonstrated the antibacterial and antibiofilm activities of medicinal plant EOs, especially T. zygis and O. majorana. Therefore, we propose these oils as alternatives to antibiotics and potential sources of new chemotherapeutic drugs because of their diverse and nontoxic effect.

\section{Materials and Methods}

\subsection{Sampling and Bacterial Strains Identification}

Urine samples were from patients with clinical symptoms of urinary tract infection (UTI) referred to King Abdulaziz Specialist Hospital in Taif, Saudi Arabia. Their ages ranged from two months to 90 years. Clean-Catch midstream urine of the patients was collected in a sterile tube $(4-5 \mathrm{~mL})$ and immediately transported to the laboratory for analysis. A label containing age and gender identified the tubes.

All samples of urine were inoculated on blood agar as well as MacConckey agar and incubated at $37^{\circ} \mathrm{C}$ for $24 \mathrm{~h}$, and for $48 \mathrm{~h}$ in negative cases. A specimen was considered positive for UTI in light of the number of yielded colonies $\left(\geq 10^{5} \mathrm{CFU} / \mathrm{mL}\right)$. E. coli isolates were identified by standard biochemical tests and were confirmed using Api 20E system (Bio-merieux, Marcy-l'Étoile, France).

\subsection{Essential Oils}

Five commercial medicinal plant EOs were purchased from Laboratoires OMEGA Pharma (Groupe Perrigo) - Phytosun Arôms (France) and maintained at $4{ }^{\circ} \mathrm{C}$ in dark glass vials until used. These oils were isolated from J. communis (54K9X2), Z. officinale (M14229), O. majorana (74K100C6), T. zygis (M13184) and R. officinalis (M16084). These EOs were selected for their antibacterial and/or antibiofilm actions reported in literature [11-15] and their use in traditional medicine.

\subsection{Gas Chromatography—Mass Spectrometry Analysis}

GC analysis was performed as previously described [46]. 


\subsection{Screening for Antibacterial Activity of Essential Oils}

\subsubsection{Disc Diffusion}

Antibacterial activity was examined by the agar disc diffusion method [47]. Bacteria were first grown on Mueller Hinton plates at $37^{\circ} \mathrm{C}$ for $18-24 \mathrm{~h}$ prior to inoculation onto the nutrient agar. Bacterial suspensions were prepared in saline water and adjusted to $0.5 \mathrm{McFarland}$ turbidity standards with a DENSIMAT (Bio-merieux, Marcy-l'Étoile, France).

Bacterial inoculums were streaked onto Mueller-Hinton agar (MHA) agar plates using a sterile swab. A sterile filter disc (diameter $6 \mathrm{~mm}$, Whatman paper $\mathrm{N}^{\circ} 3$ ) was used. The disc was impregnated by the tested EOs $\left(10 \mu \mathrm{L} /\right.$ disc). The Petri dishes were placed at $4{ }^{\circ} \mathrm{C}$ for $1-2 \mathrm{~h}$ and then incubated at $37^{\circ} \mathrm{C}$ for $18-24 \mathrm{~h}$. Antibacterial activity was evaluated by measuring the zone of growth inhibition around the discs after $24 \mathrm{~h}$ of incubation at $37^{\circ} \mathrm{C}$. Standard discs $(6 \mathrm{~mm}$ diameter) of the antibiotic Gentamycin $(10 \mu \mathrm{g})$ served as positive antibacterial control. Inhibition zone diameters around each disc were taken as a measure of antibacterial activity.

Inhibitory action was categorized according to the zone of inhibition (ZI) as described by El-Deeb et al. [48]. These categories were: Strong inhibitory action $(++++), Z \mathrm{I}>/=22 \mathrm{~mm}$; complete inhibitory action (+++), ZI = 18-21 mm; partial inhibitory action (++), ZI = 14-17 mm, slight inhibitory action (+), $\mathrm{ZI} \leq 13 \mathrm{~mm}$ or no inhibitory action $(-), \mathrm{ZI}=0$. Each experiment was carried out in triplicate and the mean diameter of the inhibition zone was recorded.

\subsubsection{Determination of MIC and MBC}

The minimal inhibition concentration (MIC) and the minimal bactericidal concentration (MBC) values were determined for all isolates as described by Gulluce et al. [49]. Bacterial strain inoculums were prepared from $12 \mathrm{~h}$ broth cultures and suspensions were adjusted to $0.5 \mathrm{McF}$ arland standard turbidity. EOs were first diluted to the highest concentration $(50 \mathrm{mg} / \mathrm{mL})$ to be tested, and then serial two-fold dilutions were made in $5 \mathrm{~mL}$ of nutrient broth with concentrations ranging from $0.012-50 \mathrm{mg} / \mathrm{mL}$. The $96-w e l l$ plates were prepared by dispensing $95 \mu \mathrm{L}$ of nutrient broth and $5 \mu \mathrm{L}$ of the inoculum into each well. A $100 \mu \mathrm{L}$ aliquot from the stock solutions of each EO was added into the first well. Then, $100 \mu \mathrm{L}$ from the serial dilutions were transferred into 11 consecutive wells. The last well was used as the negative control containing $195 \mu \mathrm{L}$ of nutrient broth without EO and $5 \mu \mathrm{L}$ of the inoculum. The final volume in each well was $200 \mu \mathrm{L}$. The plates were incubated at $37^{\circ} \mathrm{C}$ for $18-24 \mathrm{~h}$. The experiment was carried out in duplicate. The MIC was defined as the lowest concentration of the compounds to inhibit the growth of the microorganisms. The MBC values were determined by subculturing $20 \mu \mathrm{L}$ from clear wells of the MICs test on MHA. MBC values were defined as the lowest concentration of sample, which resulted in $\geq 99.9 \%$ kill of the initial inoculum [50]. The experiments were carried out in triplicates.

\subsection{Biofilm Formation}

Biofilm formation by E. coli isolates was determined using 96-well microtiter plates, as described previously [51]. Strains were grown in Trypticase Soy broth (TSB, Pronadisa, Spain). Following overnight incubation at $37{ }^{\circ} \mathrm{C}$, the optical density (OD600) of bacterial culture was measured. An overnight culture, grown in TSB at $37{ }^{\circ} \mathrm{C}$, was diluted to 1:100 in TSB supplement with $2 \%$ $(w / v)$ glucose. $200 \mu \mathrm{L}$ of cell suspensions was transferred in a U-bottomed 96-well microtiter plate (Nunc, Roskilde, Denmark). Each strain was tested in triplicate. Wells with sterile TSB alone served as controls. After incubation at $37^{\circ} \mathrm{C}$ for $24 \mathrm{~h}$, the cultures were removed and the plates were washed twice with phosphate-buffered saline $\left(7 \mathrm{mM} \mathrm{Na}_{2} \mathrm{HPO}_{4}, 3 \mathrm{mM} \mathrm{NaH}_{2} \mathrm{PO}_{4}\right.$ and $130 \mathrm{mM} \mathrm{NaCl}$ at pH 7.4) to remove non-adherent cells and dried in an inverted position. Adherent cells were fixed with $95 \%$ ethanol and stained with $100 \mu \mathrm{L}$ of $1 \%$ crystal violet (Merck, France) for $5 \mathrm{~min}$. The excess stain was rinsed and poured off and the wells were washed three times with $300 \mu \mathrm{L}$ of sterile distilled water. The water was then cleared and the microplates were air-dried. The optical density of each 
well was measured at $570 \mathrm{~nm}$ (OD570) using an automated Multiskan reader (GIO. DE VITA E C, Rome, Italy). Biofilm formation was interpreted as highly positive (OD570 $\geq 1$ ), low-grade positive $(0.1 \leq$ OD570 $<1)$, or negative (OD570 < 0.1).

\subsection{Inhibition of Biofilm Formation}

One hundred microliters of the EOs emulsified in TSB supplement with $2 \%$ glucose were added to the U-bottomed 96-well microtiter plate containing $100 \mu \mathrm{L}$ of bacterial suspensions $\left(10^{8} \mathrm{CFU} / \mathrm{mL}\right)$ in each well. The final concentrations of the EOs were equivalent to MIC and the final volume was $200 \mu \mathrm{L}$ per well. The assays were conducted in triplicate. After incubation of microplates at $37^{\circ} \mathrm{C}$ for $24 \mathrm{~h}$, the formed biofilm was quantified by crystal violet as described previously. Controls were prepared by replacing the inoculums volume by TSB, and EOs by sterile water. Inhibition of biofilm was determined from the formula described by Jadhav et al. [52]:

$$
\% \text { Inhibition }=100-\left(\frac{\text { OD570 sample }}{\text { OD570 control }} \times 100\right)
$$

\subsection{Statistical Analysis}

Statistical analysis was conducted using analysis of variance (ANOVA). Pearson's simple linear correlation coefficient $(r)$ and their significance $(p)$ were calculated using SPSS 20.

Author Contributions: F.B.A. and R.L. conceived and designed the experiments; R.L. and B.O.A.-S. performed the experiments; Y.A.-S. analyzed the results with the software, F.B.A. wrote, reviewed and edited the paper.

Funding: This research received no external funding.

Acknowledgments: The authors would like to thank the teams at the microbiological analysis laboratory at King Abdulaziz Specialist Hospital, Taif, Saudi Arabia for help in sampling and bacterial isolation and Laboratoires OMEGA Pharma (Groupe Perrigo) - Phytosun Arôms (France) for help in the GC-MS analysis.

Conflicts of Interest: The authors declare no conflict of interest.

\section{References}

1. Toro, C.S.; Farfan, M.; Contreras, I.; Flores, O.; Navarro, N.; Mora, G.C.; Prado, V. Genetic analysis of antibiotic-resistance determinants in multidrug-resistant Shigella strains isolated from Chilean children. Epidemiol. Infect. 2005, 133, 81-86. [CrossRef] [PubMed]

2. Kunin, C.M. Urinary tract infections in females. Clin. Infect. Dis. 1994, 18, 1-12. [CrossRef] [PubMed]

3. Foxman, B. Epidemiology of urinary tract infections: Incidence, morbidity, and economic costs. Am. J. Med. 2002, 113, S1-S5. [CrossRef]

4. El-Kersh, T.A.; Marie, M.A.; Al-Sheikh, Y.A.; Al-Kahtani, S.A. Prevalence and risk factors of communityacquired urinary tract infections due to ESBL- producing Gram negative bacteria in an Armed Forces Hospital in Sothern Saudi Arabia. JMMS 2015, 4, 2315-5159.

5. Lin, E.; Bhusal, Y.; Horwitz, D.; Shelburne, S.A.; Trautner, B.W. Overtreatment of Enterococcal Bacteriuria. Arch. Intern. Med. 2012, 172, 33-38. [CrossRef]

6. Costerton, J.W.; Stewart, P.S.; Greenberg, E.P. Bacterial biofilms: A common cause of persistent infections. Science 1999, 284, 1318-1322. [CrossRef] [PubMed]

7. Tabibian, J.H.; Gornbein, J.; Heidari, A.; Dien, S.L.; Lau, V.H.; Chahal, P.; Churchill, B.M.; Haake, D.A. Uropathogens and Host Characteristics. J. Clin. Microbiol. 2008, 46, 3980-3986. [CrossRef] [PubMed]

8. Stewart, P.S. Mechanisms of antibiotic resistance in bacterial biofilms. Int. J. Med. Microbiol. 2002, 292, 107-113. [CrossRef] [PubMed]

9. Flemming, H.; Wingender, J. The biofilm matrix. Nat. Rev. Microbiol. 2010, 8, 623-633. [CrossRef]

10. Romling, U.; Balsalobre, C. Biofilm infections, their resilience to therapy and innovative treatment strategies. J. Intern. Med. 2012, 272, 541-561. [CrossRef] [PubMed]

11. Pepeljnjak, S.; Kosalec, I.; Kalodera, Z.; Blazevic, N. Antimicrobial activity of juniper berry essential oil (Juniperus communis L., Cupressaceae). Acta Pharm. 2005, 55, 417-422. [PubMed] 
12. Sivasothy, Y.; Chong, W.K.; Hamid, A.; Eldeen, I.M.; Sulaiman, S.F.; Awang, K. Essential oils of Zingiber officinale var. rubrum Theilade and their antibacterial activities. Food Chem. 2011, 124, 514-517. [CrossRef]

13. Marquesa, J.L.; Volcãob, L.M.; Funcka, G.D.; Kroninga, I.S.; da Silvaa, W.P.; Fiorentinia, Â.M.; Ribeiroca, G.A. Antimicrobial activity of essential oils of Origanum vulgare L. and Origanum majorana L. against Staphylococcus aureus isolated from poultry meat. Ind. Crops. Prod. 2015, 77, 444-450. [CrossRef]

14. Yakoubi, S.; Cherrat, A.; Diouri, M.; EL Hilali, F.; Zair, T. Chemical composition and antibacterial activity of Thymus zygis subsp. gracilis (Boiss.) R. Morales essential oils from Morocco. Med. J. Chem. 2014, 3, 746-758.

15. Jardak, M.; Elloumi-Mseddi, J.; Aifa, S.; Mnif, S. Chemical composition, anti-biofilm activity and potential cytotoxic effect on cancer cells of Rosmarinus officinalis L. essential oil from Tunisia. Lipids Health Dis. 2017, 16, 190. [CrossRef] [PubMed]

16. Abdalá, A.E.; Roozen, J.P. The effects of stabilized extracts of sage and oregano on the oxidation of salad dressings. Eur. Food Res. Technol. 2011, 212, 551-560. [CrossRef]

17. Burt, S. Essential oils: Their antibacterial properties and potential applications in foods-a review. Inter. J. Food Microbiol. 2004, 94, 223-253. [CrossRef]

18. Cowan, M.M. Plant products as antimicrobial agents. Clin. Microbiol. Rev. 1999, 12, 564-565. [CrossRef] [PubMed]

19. Kordali, S.; Kotan, R.; Mavi, A.; Cakir, A.; Ala, A.; Yildirim, A. Determination of the chemical composition and antioxidant activity of the essential oil of Artemisia dracunculus and of the antifungal and antibacterial activities of turkish Artemisia absinthium, A. dracunculus, Artemisia santonicum, and Artemisia spicigera essential oils. J. Agric. Food Chem. 2005, 53, 9452-9458. [PubMed]

20. Prabuseenivasan, S.; Jayakumar, M.; Ignacimuthu, S. In vitro antibacterial activity of some plant essential oils. BMC Compl. Altern. Med. 2006, 6, 39. [CrossRef]

21. Wojnicz, D.; Kucharska, A.Z.; Sokól-Letowska, A.; Kicia, M.; Tichaczek-Goska, D. Medicinal plants extracts affect virulence factors expression and biofilm formation by the uropathogenic Escherichia coli. Urol. Res. 2012, 40, 683-697. [CrossRef] [PubMed]

22. Kim, H.S.; Park, H.D. Ginger extract inhibits biofilm formation by Pseudomonas aeruginosa PA14. PLoS ONE 2013, 8, e76106. [CrossRef] [PubMed]

23. Huma, J.; Fohad, M.H.; Iqbal, A. Antibacterial and antibiofilm activity of some Essential oils and compounds against clinical strains of Staphylococcus aureus. J. Biomed. 2014, 1, 65-71.

24. Nazzaro, F.; Fratianni, F.; De Martino, L.; Coppola, R.; De Feo, V. Effect of essential oils on pathogenic bacteria. Pharmaceuticals 2013, 6, 1451-1474. [CrossRef] [PubMed]

25. Tiwari, B.K.; Valdramidis, V.P.; O'Donnel, C.P.; Muthukumarappan, K.; Bourke, P.; Cullen, P.J. Application of natural antimicrobials for food preservation. J. Food Chem. 2009, 57, 5987-6000. [CrossRef] [PubMed]

26. Bano, K.; Khan, J.; Begum, R.H.; Munir, S.; Akbar, N. Patterns of antibiotic sensitivity of bacterial pathogens among urinary tract infections (UTI) patients in a Pakistani population. J. Microbiol. Res. 2012, 6, 414-420.

27. Ramanath, K.; Shafiya, S. Prescription pattern of antibiotic usage for urinary tract infection treated in a rural tertiary care hospital. J. Pharm. 2011, 2, 57-63.

28. Iqbal, T.; Naqvi, R.; Akhter, S.F. Frequency of urinary tract infection in renal transplant recipients and effect on graft function. J. Pak. Med. 2010, 10, 826-829.

29. Daoud, Z.; Afif, C. Escherichia coli Isolated from Urinary Tract Infections of Lebanese Patients between 2000 and 2009: Epidemiology and Profiles of Resistance. Chemother. Res. Pract. 2011, 2011, 218431. [CrossRef] [PubMed]

30. Kumar, M.; Lakshmi, V.; Rajagopalan, R. Occurrence of extended spectrum $\beta$-lactamases among Enterobacteriaceae spp. isolated at tertiary care Institute. J. Med. Microbiol. 2006, 24, 208-211.

31. Pattnaik, S.; Subramanyam, V.R.; Bapaji, M.; Kole, C.R. Antibacterial and antifungal activity of aromatic constituents of essential oils. Microbios 1997, 89, 39-46.

32. Ouedrhiria, W.; Mounyr, B.; Harkib, H.; Mojac, S.; Grechea, H. Synergistic antimicrobial activity of two binary combinations of marjoram, lavender, and wild thyme essential oils. Int. J. Food Prop. 2017, 12, 3149-3158. [CrossRef]

33. Santoyo, S.; Cavero, S.; Jaime, L.; Ibanez, E.; Senorans, F.J.; Reglero, G. Chemical composition and antimicrobial activity of Rosmarinus officinalis L. essential oil obtained via supercritical fluidextraction. J. Food Prot. 2005, 68, 790-795. [CrossRef] 
34. Li, L.; Li, Z.W.; Yin, Z.Q.; Wei, Q.; Jia, R.Y.; Zhou, L.J.; Xu, J.; Song, X.; Zhou, Y.; Du, Y.H.; et al. Antibacterial activity of leaf essential oil and its constituents from Cinnamomum longepaniculatum. Int. J. Clin. Exp. Med. 2014, 7, 1721-1727. [PubMed]

35. Dorman, H.J.D.; Deans, S.G. Antimicrobial agents from plants: Antibacterial activity of plant volatile oils. J. Appl. Microbiol. 2000, 88, 308-316. [CrossRef]

36. Faleiro, M.L.; Miguel, M.G.; Ladeiro, F.; Venâncio, F.; Tavares, R.; Brito, J.C.; Figueiredo, A.C.; Barroso, J.G.; Pedro, L.G. Antimicrobial activity of essential oils isolated from Portuguese endemic species of Thymus. Lett. Appl. Microbiol. 2002, 36, 35-40. [CrossRef]

37. Trombetta, D.; Castelli, F.; Sarpietro, M.G.; Venuti, V.; Cristani, M.; Daniele, C.; Saija, A.; Mazzanti, G.; Bisignano, G. Mechanisms of antibacterial action of three monoterpenes. Antimicrob. Agents. Chemother. 2005, 49, 2474-2478. [CrossRef] [PubMed]

38. Tenke, P.; Kovacs, B.; Jackel, M.; Nagy, E. The role of biofilm infection in urology. World. J. Urol. 2006, 24, 13-20. [CrossRef]

39. Aminov, R.I. Horizontal gene exchange in environmental microbiota. Front. Microbiol. 2011, 2, 158. [CrossRef]

40. Sandasi, M.; Leonard, C.M.; Viljoen, A.M. The effect of five common essential oil components on Listeria monocytogenes biofilms. Food Control 2008, 19, 1070-1075. [CrossRef]

41. Nuryastuti, T.; Van der Mei, H.C.; Busscher, H.J.; Iravati, S.; Aman, A.T.; Krom, B.P. Effect of cinnamon oil on icaA expression and biofilm formation by Staphylococcus epidermidis. Appl. Environ. Microbiol. 2009, 75, 6850-6855. [CrossRef] [PubMed]

42. Hendry, E.R.; Worthington, T.; Conway, B.R.; Lambert, P.A. Antimicrobial efficacy of eucalyptus oil and 1,8-cineole alone and in combination with chlorhexidine digluconate against microorganisms grown in planktonic and biofilm cultures. J. Antimicrob. Chemother. 2009, 64, 1219-1225. [CrossRef] [PubMed]

43. Karpanen, T.J.; Worthington, T.; Hendry, E.R.; Conway, B.R.; Lambert, P.A. Antimicrobial efficacy of chlorhexidine digluconate alone and in combination with eucalyptus oil, tea tree oil and thymol against planktonic and biofilm cultures of Staphylococcus epidermidis. J. Antimicrob. Chemother. 2008, 62, 1031-1036. [CrossRef] [PubMed]

44. Ceylan, O.; Uğur, A.; Saraç, N.; Ozcan, F.; Baygar, T. The in vitro antibiofilm activity of Rosmarinus officinalis L. essential oil against multiple antibiotic resistant Pseudomonas sp. and Staphylococcus sp. J. Food. Agric. Environ. 2014, 12, 82-86.

45. Nostro, A.; Roccaro, A.S.; Bisignano, G.; Marino, A.; Cannatelli, M.A.; Pizzimenti, F.C.; Cioni, P.L.; Procopio, F.; Blanco, A.R. Effects of oregano, carvacrol and thymol on Staphylococcus aureus and Staphylococcus epidermidis biofilms. J. Med. Microbiol. 2007, 56, 519-523. [CrossRef] [PubMed]

46. Gooréa, S.G.; Ouattara, Z.A.; Yapi, A.T.; Békro, Y.A.; Bighelli, A.; Paoli, M.; Tomi, F. Chemical composition of the leaf oil of Artabotrys jollyanus from Côte d'Ivoire. Rev. Bras. Farmacogn. 2017, 27, 414-418.

47. Bagamboula, C.; Uyttendaele, M.; Debevere, J. Inhibitory effect of thyme and basil essential oils, carvacrol, thymol, estragol, linalool and p-cymene towards Shigella sonnei and S. flexneri. J. Food microbiol. 2004, 21, 33-42. [CrossRef]

48. El-Deeb, B.; Elhariry, H.; Mostafa, N.Y. Antimicrobial Activity of Silver and Gold Nanoparticles Biosynthesized Using Ginger Extract. Res. J. Pharm. Biol. Chem. Sci. 2016, 7, 1085.

49. Gulluce, M.; Sahin, F.; Sokmen, M. Antimicrobial and antioxidant properties of the essential oils and methanol extract from Mentha longifolia L. Food Chem. 2007, 103, 1449-1456. [CrossRef]

50. Oulkheir, S.; Aghrouch, M.; El Mourabit, F.; Dalha, F.; Graich, H.; Amouch, F.; Ouzaid, K.; Moukale, A.; Chadli, S. Antibacterial Activity of Essential Oils Extracts from Cinnamon, Thyme, Clove and Geranium Against a Gram Negative and Gram Positive Pathogenic Bacteria. JDMP 2017, 3, 1-5.

51. Ben Abdallah, F.; Chaieb, K.; Zmantar, T.; Kallel, H.; Bakhrouf, A. Adherence assays and Slime production of Vibrio alginolyticus and Vibrio parahaemolyticus. Braz. J. Microbiol. 2009, 40, 394-398. [CrossRef] [PubMed]

52. Jadhav, S.; Shah, R.; Bhave, M.; Palombo, E.A. Inhibitory activity of yarrow essential oil on Listeria planktonic cells and biofilms. J. Food Control. 2013, 29, 125-130. [CrossRef]

Sample Availability: Not available.

(C) 2019 by the authors. Licensee MDPI, Basel, Switzerland. This article is an open access article distributed under the terms and conditions of the Creative Commons Attribution (CC BY) license (http://creativecommons.org/licenses/by/4.0/). 